\title{
Regulatory and institutional developments in the Ontario wine and grape industry
}

\author{
This article was published in the following Dove Press journal: \\ International Journal of Wine Research \\ 25 September 2012 \\ Number of times this article has been viewed
}

\author{
Richard Carew' \\ Wojciech J Florkowski \\ 'Agriculture and Agri-Food \\ Canada, Pacific Agri-Food Research \\ Centre, Summerland, BC, Canada; \\ ${ }^{2}$ Department of Agricultural and \\ Applied Economics, University of \\ Georgia, Griffin, GA, USA
}

\begin{abstract}
The Ontario wine industry has undergone major transformative changes over the last two decades. These have corresponded to the implementation period of the Ontario Vintners Quality Alliance (VQA) Act in 1999 and the launch of the Winery Strategic Plan, "Poised for Greatness," in 2002. While the Ontario wine regions have gained significant recognition in the production of premium quality wines, the industry is still dominated by a few large wine companies that produce the bulk of blended or "International Canadian Blends" (ICB), and multiple small/mid-sized firms that produce principally VQA wines. This paper analyzes how winery regulations, industry changes, institutions, and innovation have impacted the domestic production, consumption, and international trade, of premium quality wines. The results of the study highlight the regional economic impact of the wine industry in the Niagara region, the success of small/mid-sized boutique wineries producing premium quality wines for the domestic market, and the physical challenges required to improve domestic VQA wine retail distribution and bolster the international trade of wine exports. Domestic success has been attributed to the combination of natural endowments, entrepreneurial talent, established quality standards, and the adoption of improved viticulture practices.
\end{abstract}

Keywords: Ontario, wine, quality standards

\section{Introduction}

The Canadian wine industry underwent a major transformation following the enactment of the Canada/US Free Trade Agreement (CUSFTA) in 1989 and the adoption of policies in the early 1990s to promote the production of premium quality wines. The Ontario Vintners Quality Alliance (VQA) Act (1999) allowed consumers to identify quality wines made in Ontario, based on the origin of the grapes, quality of the vintage, and production methods. ${ }^{1}$ Such regulatory measures created incentives for small ( $<20,000$ cases per annum) and mid-sized wineries (20,000-100,000 cases per annum) to alter production strategies and improve consumer acceptance.

Ontario accounts for the bulk of Canadian premium wine production, produces $90 \%$ of the wine, and grows $80 \%$ of the harvestable grapes in Canada. This wine region demonstrates how a minor wine-producing area in the international wine industry can develop a dynamic, competitive industry within a relatively short time, through the combination of innovation, entrepreneurial talent, and increased wine tourism.

This paper analyzes the performance of the Ontario wine and grape industries in terms of a combination of institutional, structural, and market development factors. The role the Liquor Control Board of Ontario (LCBO), industry organizations, support institutions, and regulations have played in the development and 
enhanced competitiveness of the Ontario wine region is also considered. The next section reviews the Canadian and Ontario wine and grape industries, wine distribution, and industry policies. Government regulations and their influence on the importation and interprovincial movement of wine products and effects on direct market sales across provincial boundaries, are addressed in this section. The third section examines the Ontario grape industry in terms of varietals grown and pricing practices. The fourth section examines the role of technological change and Research and Development (R\&D) institutions in providing improved viticulture innovations for uptake by the grape and winery establishments. Concluding remarks are provided in the final section.

\section{The Canadian wine industry}

The Canadian wine industry has a long history, starting in 1927 when the LCBO was instituted to regulate the import and retail sale of alcoholic beverages, to the establishment of the 1999 VQA appellation system to develop standards rating and certifying quality wines. ${ }^{2}$ In the early days, the Canadian wine industry was based on the cultivation of hardy native grape species (eg, Vitis labrusca) and the production of fortified and sweet table wines. ${ }^{3,4}$ The 1960 s were marked by a shift in Canadians' consumption habits to drier wines, mainly port and sherry types. ${ }^{5}$ The development of the modern Canadian wine industry commenced with the advent of the CUSFTA in 1989 and the subsequent adoption of wine regulations to promote the production of premium quality wines. New wine regulation resulted in the phase-out of Canada's protectionist wine tariff structure, increased plantings of European grape varieties ( $V$. vinifera), and improved wine quality and global competitiveness of Canadian wines. ${ }^{5}$

The Canadian wine industry is small by North American standards when compared with large US wine regions such as California and Washington. Canadian manufacturing wine value-added totaled CAD \$593 million (mln) and total employment of 3567 persons in $2009 .{ }^{6}$ Since 1998 , the Canadian wine sector has accounted for about $0.3 \%$ of the manufacturing sector with an average annual real GDP growth rate of $7.6 \%{ }^{7}$ The expansion of the Canadian winery industry since the late $1990 \mathrm{~s}$ is attributed to improved quality standards and expanded promotion of Canadian wines., ${ }^{2,3}$

The bulk of the Canadian wine industry is concentrated in Ontario followed by British Columbia (BC), Quebec, and Nova Scotia. In 2009, there were 364 Canadian grape wineries, up from 299 in 2006, with most of them located in $\mathrm{BC}$ and Ontario. ${ }^{8}$ Canadian wineries, liquor stores, and agencies reported wine sales valued at CAD $\$ 5.8$ billion in 2010, up from CAD $\$ 2.4$ billion in $1998 .^{9}$ The growth of sales value exceeded the growth of volume. The corresponding increase in volume sales is $76 \%$, from 259.9 million liters (milL) in 1998 to 456.4 milL in 2010. Much of the growth in wine sales can be attributed to the rising popularity of red wines; red and rosé wines account for $62 \%$ of total volume sales. ${ }^{10}$ Import volumes accounted for approximately $50 \%$ of Canadian domestic wine sales with Canadian import volumes increasing by $73 \%$ from 203 milL in 1998 to 350 milL in 2010 (Table 1). ${ }^{11}$ There has been a slight declining trend in Canadian bulk wine imports from the US over the last few years. ${ }^{12}$ Bulk wines are less expensive to transport and account for about $40 \%$ of Canada wine imports from the United States.

Canada is a relatively small player on the international wine market with export sales totaling CAD \$28 mln in 2010, up from CAD \$6 mln in 1998. As shown in Table 2, Canadian wine exports to the world had increased from 1.2 milL in 1998 to 14.9 milL by 2010 with the bulk destined for the United States. ${ }^{11}$ Wine exports from Ontario represent a large portion of the country's total wine exports' share, which declined from $49.5 \%$ in 1998 to $24.1 \%$ in 2010 . Although more wine has been exported in relative and absolute terms from Ontario and Canada recently, the American market is slightly less important for Ontario wines (Ontario's 89.7\% versus Canada's 94.0\%) than Canadian overall wine shipments. The most noticeable difference in wine exports from Ontario and Canada has been the almost complete cessation of exports to major Asian markets, with the exception of the emerging wine market in China. Also, the importance of the European market has diminished, except for, surprisingly, the increase in wine exports from Ontario to France. National export wine programs have been developed by the federal government to bolster the exports of Canadian wine to selected foreign markets and US cities. ${ }^{13}$

Shifting trends in the production of higher quality wines have impacted the structure of the Canadian wine sector. In the 1990s, Vincor International Inc (Canada's largest winery), consolidated its operations by acquiring vineyards and investing in the growing of the high-quality premium European grapes required to produce premium wines. ${ }^{14}$ Vincor's expansion strategy in foreign markets included strengthening its technical capability by procuring wine-making technology, wine makers, and vineyard managers from reputable wine-producing countries. Vincor acquired a portfolio of mid-sized or estate wineries in Canada along with sales distribution networks in California. By 2004, Vincor had extended its operations 
Table I A comparison of Ontario and Canadian wine imports between 1998 and $2010^{\text {a }}$

\begin{tabular}{|c|c|c|c|c|c|c|}
\hline \multirow[t]{2}{*}{ Importing country } & \multicolumn{3}{|l|}{1998} & \multicolumn{3}{|l|}{2010} \\
\hline & Volume (liters) & Volume (percent) & Rank & Volume (liters) & Volume (percent) & Rank \\
\hline \multicolumn{7}{|l|}{ Canada } \\
\hline US & $38,677,950$ & 19.1 & 2 & $49,828,185$ & 14.2 & 4 \\
\hline Total & $202,925,488$ & & & $350,058,992$ & & \\
\hline \multicolumn{7}{|l|}{ Ontario } \\
\hline France & $22,839,257$ & 30.5 & 1 & $13,138,840$ & 11.7 & 4 \\
\hline Italy & $13,629,242$ & 18.2 & 2 & $24,4 \mid 2,330$ & 21.7 & I \\
\hline US & $|3,377,13|$ & 17.8 & 3 & $\mid 4,562,208$ & 12.9 & 3 \\
\hline Australia & $4,067,805$ & 5.4 & 5 & $16,218,596$ & 14.4 & 2 \\
\hline Chile & $7,944,644$ & 10.6 & 4 & $12,069,803$ & 10.7 & 5 \\
\hline Portugal & $2,078,395$ & 2.7 & 7 & $2,464,892$ & 2.2 & \\
\hline Germany & $2,237,038$ & 2.9 & 6 & $2,077,645$ & 1.8 & \\
\hline Spain & $|, 910,07|$ & 2.5 & 8 & $6,518,684$ & 5.8 & 7 \\
\hline South Africa & I,899,736 & 2.5 & 8 & $6,072,532$ & 5.4 & 8 \\
\hline New Zealand & 289,331 & 0.4 & & $3,103,502$ & 2.8 & \\
\hline Argentina & 985,370 & 1.3 & & $9,846,907$ & 8.7 & 6 \\
\hline Greece & 847,926 & I.I & & 378,598 & 0.3 & \\
\hline Hungary & 973,238 & 1.3 & & $\mathrm{I}, 024,605$ & 0.9 & \\
\hline Bulgaria & 552,624 & 0.7 & & 33,535 & 0.03 & \\
\hline Israel & $|36,58|$ & 0.2 & & 122,406 & 0.1 & \\
\hline Others & I,002,677 & 1.3 & & 659,016 & 0.6 & \\
\hline Total & $74,771,066$ & 100 & & II2,704,099 & 100 & \\
\hline
\end{tabular}

Note: ancludes wine of fresh grapes including fortified wines, iced wines, and grape must. Based on data from Guilbault (201I)."

globally through the acquisitions of product brands in the US, New Zealand, Australia, and South Africa. ${ }^{15}$

\section{Canadian wine demand, distribution and regulations}

The increasing popularity of wines is attributed to the popularity of red wines. The consumed wine volume per adult for both red and white wines increased from 11.3 liters in 1998 to 16.8 liters in $2010 .{ }^{16}$ Canadian wine consumption levels are relatively low when compared on a global basis, but this is likely to be influenced in the near future by the changing demographic make-up of wine drinkers. ${ }^{17}$ Most of the growth in Canadian wine consumption has been associated with a rapid increase in the consumption of premium quality wines. Ontario VQA table wine sales increased by an impressive $78 \%$ from CAD $\$ 162 \mathrm{mln}$ in $2001 / 02$ to CAD $\$ 288 \mathrm{mln}$ in 2010/11 but in relative terms were outpaced by the British Columbia VQA wine sales, which increased by $175 \%$ from CAD $\$ 70 \mathrm{mln}$ to CAD $\$ 193 \mathrm{mln}$ over the same period. ${ }^{18,19}$

After Canadian Prohibition was repealed in 1927, the responsibility to regulate the sale of alcohol was assigned to provincial governments through the enactment of Canada's federal Importation of Intoxicating Liquors Act in 1928. This Act granted the provincial liquor control boards monopolistic power over the importation, inter-provincial shipment, and retailing of wine in Canada. ${ }^{20}$ The boards are the only entities that can legally import wine into Canada and, with the exception of Alberta, own and operate retail stores. ${ }^{21}$ Alberta privatized alcohol retailing in 1993 .

In general, the bulk of wine retail sales occur through Provincial Government-owned and licensed liquor stores. However, the two large wineries (Vincor, Andrew Peller Ltd) in Ontario that have brand recognition own most of the 368 private retail stores in Ontario. ${ }^{22}$ VQA premium quality wines produced by small/mid-sized wineries are generally sold through on-site winery stores, off-site private stores, and restaurants. Inter-provincial wine trade restrictions have limited business opportunities in Ontario to domestic wine sales within provincial jurisdictions. It is still illegal, for example, to ship wine directly to customers across provincial borders in Canada without going through their liquor control board. The limited production of small boutique wineries impedes them from shipping to government retail liquor stores and restricts Canadians' access to some of the best wines. The removal of the inter-provincial trade restrictions would offer an alternative distribution channel, and allow direct sales from small wineries to consumers in provinces without a wine industry. 
Table 2 A comparison of Ontario and Canada wine volume exports to principal importing countries in 1998 and $2010^{a}$

\begin{tabular}{|c|c|c|c|c|}
\hline \multirow[t]{2}{*}{ Country } & \multicolumn{2}{|l|}{1998} & \multicolumn{2}{|l|}{2010} \\
\hline & Volume (liters) & Volume (percent) & Volume (liters) & Volume (percent) \\
\hline \multicolumn{5}{|l|}{ Canada } \\
\hline US & 134,537 & 11.0 & $|4,007,23|$ & 94.0 \\
\hline Taiwan & 387,392 & 31.7 & $24, \mid 44$ & 0.2 \\
\hline Hong Kong & 132,294 & 10.8 & 170,253 & I.I \\
\hline China & 5,530 & 0.4 & 462,132 & 3.1 \\
\hline Japan & 145,890 & 11.9 & 23,476 & 0.2 \\
\hline Singapore & 40,082 & 3.2 & 17,575 & 0.1 \\
\hline Australia & - & - & 16,086 & 0.1 \\
\hline Chile & 96,000 & 7.8 & 27 & 0.0002 \\
\hline UK & 83,143 & 6.8 & 44,817 & 0.3 \\
\hline Germany & 28,248 & 2.3 & $|6,97|$ & 0.1 \\
\hline France & - & - & 29,997 & 0.2 \\
\hline Switzerland & 10,960 & 0.8 & 11,560 & 0.1 \\
\hline Sweden & 81,282 & 6.6 & - & - \\
\hline Others & 76,662 & 6.3 & 68,994 & 0.5 \\
\hline Total & $1,222,020$ & 100 & $14,893,263$ & 100 \\
\hline \multicolumn{5}{|l|}{ Ontario } \\
\hline US & II4,903 & 19.0 & $3,219,552$ & 89.7 \\
\hline Taiwan & 208,402 & 34.5 & 9081 & 0.2 \\
\hline Hong Kong & 59,375 & 9.8 & 37,793 & 1.0 \\
\hline China & 580 & 0.1 & 171,322 & 4.7 \\
\hline Japan & 82,846 & 13.7 & 20,335 & 0.6 \\
\hline Singapore & 40,082 & 6.6 & 16,875 & 0.4 \\
\hline Malaysia & - & - & 3777 & 0.1 \\
\hline Australia & - & - & 16,086 & 0.4 \\
\hline UK & 32,981 & 5.4 & 14,327 & 0.4 \\
\hline Germany & 28,248 & 4.6 & 15,575 & 0.4 \\
\hline France & 279 & 0.04 & 18,292 & 0.5 \\
\hline Switzerland & 10,960 & 1.8 & $8|7|$ & 0.2 \\
\hline Netherlands & 1125 & 0.2 & - & - \\
\hline Others & 24,916 & 4.1 & 37,455 & 1.0 \\
\hline Total & 604,697 & 100 & $3,588,64 \mid$ & 100 \\
\hline
\end{tabular}

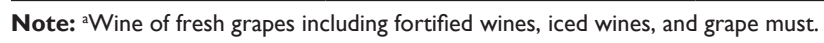
Based on data from Guilbault (201 I)."

\section{The Ontario wine industry}

The Ontario wine industry contributes to the local economy in multiple ways including manufacturing, processing, and tourism. An economic impact evaluation of the Ontario VQA wine industry estimated the value-added contribution of the sector to be CAD $\$ 191 \mathrm{mln}$ with the creation of 1300 jobs during the last five years. ${ }^{23}$

There are two categories of wine, namely VQA and ICB wines. ${ }^{24} \mathrm{ICB}$ wines are regulated under Ontario's Wine Content Act. ${ }^{5}$ In 1999, the legitimization of the VQA Act established an "Appellation of Origin" system akin to the French Appellation d'Origine Contrôlée (AOC) system, which allowed consumers to identify VQA quality wines made in Ontario, based on the appellation origin of the grapes, quality of the vintage, and viticulture methods..$^{25}$ In fiscal year 2007/08, there were over 140 licensed wineries (grape and fruit wineries) with 108 producing VQA wines. ${ }^{26}$ Wineries that are registered grape growers account for roughly $25 \%-30 \%$ of the wine grape crop and grow about $50 \%$ of the $V$. vinifera grapes used to manufacture premium quality wines. ${ }^{27}$

In Ontario, the grape and wine industry can be considered an amalgamation of several institutions and industry organizations, such as the Wine Council of Ontario (WCO) and the Grape Growers of Ontario (GGO). ${ }^{28}$ Although the GGO and LCBO seem to naturally fit the Ontario wine clusters, neither institution has played a significant role in promoting innovation and growth within the Ontario wine cluster. ${ }^{29}$ The LCBO retailing and market promotion practices have not provided measurable success for the sales performance of small and medium-sized-VQA wineries because the LCBO's mandate as a provincial monopoly is to maximize profits, purchasing wines both locally or imported to optimize its retail shelf space and advertising promotional expenditures. ${ }^{30}$ 
There are several challenges regarding wine policies and industry-specific characteristics that must be addressed for the sector to improve competitiveness and develop a regional cluster identity with distinct wine styles and flagship grape varieties. ${ }^{31}$ Some of the regulatory, institutional, and structural changes that have taken place in the Ontario wine sector over the last four decades are shown in Table 3. , $5,22,32,33^{2}$

\section{Regulatory changes}

Since 1972, the Wine Content Act has been amended multiple times to allow manufacturers of blended or ICB wine to meet consumer demand. The Wine Content amendments between
1972 and 2010 have all focused on blending imported wines with domestic wines or the minimum share of Ontario-grown product. The 1972 amendment allowed wineries to blend up to $25 \%$ of imported wine per bottle, which increased to $90 \%$ in 1993. In parallel, Ontario wine-labeling regulations established the minimum amounts of Ontario-grown product in a bottle of wine starting with the minimum of $30 \%$ in 1989 , increasing to an average of $40 \%$ of Ontario-grown product by 2010 . The loosened Ontario wine-labeling laws have tarnished the image of Canadian wines by allowing wineries to use up to $70 \%$ imported product in their wines and merchandizing them as Canadian wines in provincial liquor stores. ${ }^{34}$

Table 3 Evolutionary regulatory, licensing, institutional, and structural changes in the Ontario wine industry

\begin{tabular}{|c|c|}
\hline Year/period & Regulatory, organizational, and industry structural changes \\
\hline \multicolumn{2}{|l|}{ Regulatory } \\
\hline 1927 & Establishment of the Liquor Control Board of Ontario (LCBO) \\
\hline 1972 & Wine Content Act amended to allow wineries to blend up to $25 \%$ imported product in a bottle of wine \\
\hline 1975 & Inniskillin Winery obtains Ontario's first new winery license since 1929 \\
\hline 1980 & Wine Content Act amended to allow blending up to $30 \%$ imported product in a bottle of wine \\
\hline 1989 & Wine Content Act amended to allow a minimum of $30 \%$ Ontario-grown product in a bottle of wine \\
\hline 1989 & Voluntary Vintner's Quality Alliance (VQA) Program established by Ontario wine industry \\
\hline 1993 & New wineries licensed post- 1993 can manufacture and or sell wines made only with $100 \%$ Ontario grapes \\
\hline 1993 & Wine Content Act amended to allow blending up to $90 \%$ imported product in a bottle of wine \\
\hline 1994 & Wine Content Act amended to allow a minimum of $25 \%$ Ontario-grown product in a bottle of wine \\
\hline 1999 & The VQA Act legalized in the Ontario Provincial Legislature \\
\hline 2001 & Wine Content and Labelling Act amended to allow a minimum of $30 \%$ of Ontario-grown product \\
\hline 2010 & $\begin{array}{l}\text { Wine Content and Labelling Act amended to have blended wines packaged after September I, } 2010 \text { and } \\
\text { before March } 31,2014 \text {, to have } 40 \% \text { (average) minimum domestic content }\end{array}$ \\
\hline \multicolumn{2}{|l|}{ Institutional } \\
\hline 1974 & Wine Council of Ontario established \\
\hline 1989 & Canada-US Free Trade Agreement established - eliminates preferential treatment for domestic wines \\
\hline 2002 & A Strategic Framework established for the Ontario Wine Industry titled "Poised for Greatness" \\
\hline 2004 & Environmental Program created titled "Sustaining Wine making in Ontario: An Environmental Charter" \\
\hline 2004 & VQA Ontario announced the establishment of I I Sub-appellations in the Niagara Peninsula \\
\hline 2008 & Wine Council of Ontario developed national export wine strategy partially funded by the government \\
\hline \multicolumn{2}{|c|}{ Structural change } \\
\hline 1811 & Johann Schiller established first commercial winery in Ontario \\
\hline 1874 & Thomas Bright and FA Shirriff established Niagara Falls Wine Company \\
\hline 1906 & Establishment of the Vineland Research Station that experimented with hybrid varieties \\
\hline 1946 & Adhemar de Chaunac (French scientist) experiments with European vines, including Chardonnay \\
\hline 1960s & Canadian consumption patterns shift from fortified wines to drier wines \\
\hline Pre-1972 & Ontario's wines produced from $100 \%$ Ontario-grown grapes \\
\hline 1986 & Brights Wine Company acquires Jordan and St Michelle Cellars \\
\hline 1992 & Cartier Wine Company acquired Inniskillin wine company \\
\hline 1993 & Vincor Wine Company established and launches the Jackson-Triggs label brand \\
\hline 1996 & Vincor acquired Dumont Vins et Spiritueux, Quebec, and Okanagan Vineyards in British Columbia \\
\hline 1998 & Vincor acquired RJ Spagnols Wine and Beer Making Supplies and other wineries in Quebec \\
\hline 2000 & Vincor acquired Sumac Ridge and Hawthorne Mountain Vineyards in British Columbia \\
\hline 2001 & Vincor acquired Hogue Cellars of Washington State and established Niagara winery in Ontario \\
\hline 2002 & Vincor acquired Goundrey Wines of Western Australia \\
\hline 2003 & Vincor acquired Kim Crawford Wines of Auckland, New Zealand \\
\hline 2004 & Vincor acquired Amberley Estate of Australia and Western Wines in the United Kingdom \\
\hline 2006 & Constellation Brands (New York) acquired Vincor, Canada \\
\hline
\end{tabular}

Based on data from Wine Council of Ontario (200I) ${ }^{5}$; Asple ${ }^{2}$; Grape Growers of Ontario (2012) $)^{32}$; Bramble et al ${ }^{22}$; Bramble. ${ }^{33}$ 
The Wine Content Act has not benefitted the marketing of VQA wines by small/mid-sized wineries because wine policies have facilitated the production of ICB wines by large wineries for sale in LCBO retail stores, reducing the available shelf sale for VQA wines. Less than $2.5 \%$ of the LCBO monopoly wine product listings are dedicated to VQA wines, while ICB wines dominate the limited shelf space allocated to domestic Canadian wines in LCBO retail stores. ${ }^{35}$ It appears that the VQA Act that allowed product differentiation based on wine quality and region of origin did not improve access to the LCBO distribution system and therefore wine tourism offers an alternative distribution channel, although of limited capacity.

\section{Institutional developments}

Institutional changes that affected the structure of the wine industry include the 1974 establishment of the Wine Council of Ontario. In 1989, the CUSFTA eliminated the preferential treatment of domestic wines and increased the competition from imported wines on the Ontario market. These institutional changes created the voluntary VQA Program in 1989, which was legalized in 1999 by the Ontario Provincial Legislature. In 2004, the VQA Ontario undertook additional action to further differentiate Ontario wines from imported wines and established 11 subappellations in the Niagara Peninsula.

\section{Structural changes}

Structural changes were characterized by acquisitions and mergers of multiple wineries. The first major acquisition took place in 1986 followed by the acquisition of Inniskillin by Cartier Wine Company in 1992. In 2006, Vincor itself was purchased by Constellation Brands of New York. The interests of $90 \mathrm{small} / \mathrm{mid}$-sized wineries are represented by the WCO, which is a non-profit trade association. Effective November 2009, two large wineries and four smaller ones with a significant VQA portfolio left the WCO to form the Winery and Grower Alliance of Ontario. ${ }^{36}$

Wine marketing strategies have differed markedly between the small/mid-sized and large wineries. ${ }^{37}$ Large wineries have tended to augment their competitive advantage by carrying a wider range of product brands and package containers that appeal to consumers of varying tastes, preferences, and price points.

\section{Ontario wine demand and distribution}

Between 1998 and 2010, Ontario wines sales increased by $116 \%$ from CAD $\$ 875 \mathrm{mln}$ to CAD $\$ 1.8$ billion. ${ }^{9}$ Most of the domestic wine sales increases were attributed to higher import volumes, which increased by $51 \%$ from 75 milL in 1998 to 113 milL in 2010, as illustrated in Table $1 .{ }^{11}$ There has been a noticeable shift in the New World volume wine supply to the Ontario market, particularly from countries such as Australia, Chile, and Argentina. Among Old World wine producers, Italy is the only wine supplier that significantly increased its supply to the Ontario market. Ontario consumers are drinking more wine and wine sales per adult increased from 10.5 liters in 1998 to 14.3 liters in $2010 .{ }^{16}$ These rapid increases in wine sales per adult are partly attributed to higher incomes, with the Ontario median family income averaging CAD $\$ 65,414$ over the 2005-2009 period. $^{38}$

Since 1990, domestic retail sales of Ontario wines (VQA, non-VQA) have increased from 30 milL in 1991 to 56 milL in 2010 , with VQA wines accounting for roughly $21 \%$ of total Ontario retail wine sales over the last five years, as shown in Figure $1 .{ }^{39}$ Sales of Ontario non-VQA wine by volume were increasing until 2006 and have stagnated since then, while the volume of VQA wine sales stagnated between 2001 and 2007 and has been trending upward since then. Crop failures in 2003 and 2005 affected the volume of VQA wine sales. Ontario VQA wines have sold at a higher unit value than non-VQA wines, as illustrated in Figure 2. ${ }^{39}$ As unit prices for non-VQA wines have trended upward since 1999, the VQA wine prices showed a downward tendency between 1996 and 2003. VQA prices have started to strengthen since 2003, and reached CAD \$16/liter in 2010.

The LCBO is the principal distribution channel. VQA wine prices per bottle range from less than CAD $\$ 8$ per $750-\mathrm{mL}$ bottle equivalent to those that retail at greater than CAD $\$ 15$ per bottle, as shown in Figure 3. ${ }^{39}$ Most imported table wines are sold in price ranges of less than

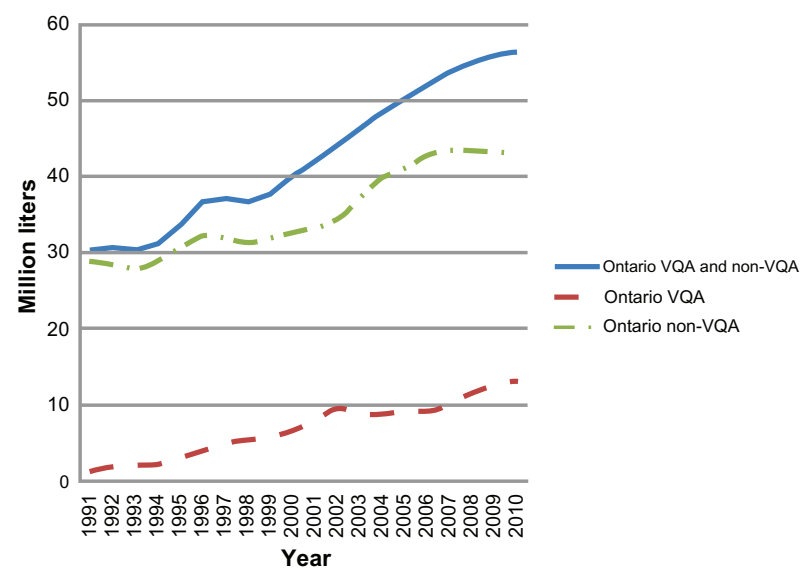

Figure I Ontario (VQA, non-VQA) domestic wine sales. Based on data from Wine Council of Ontario (20I2). ${ }^{39}$ Abbreviation: VQA, Vintners Quality Alliance. 


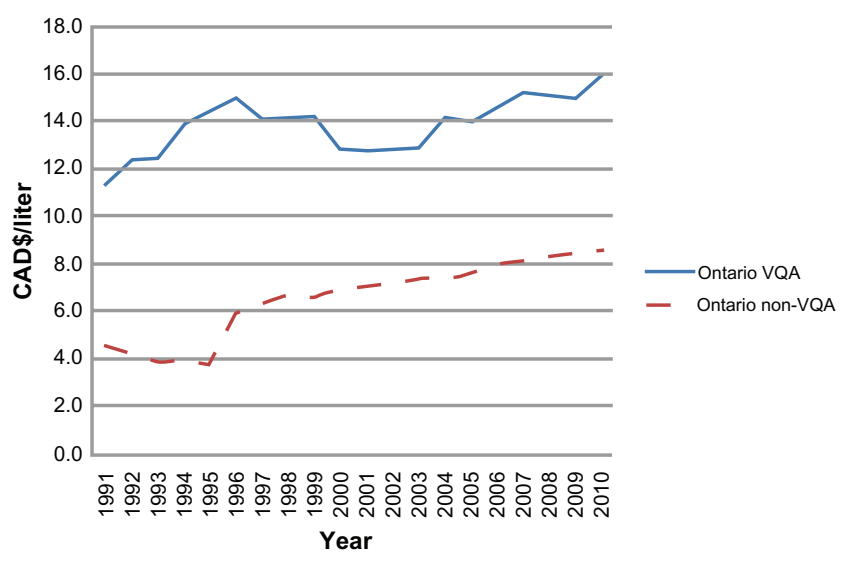

Figure 2 Unit values for Ontario VQA and Non-VQA wines. Based on data from Wine Council of Ontario (20I2). ${ }^{39}$ Abbreviation: VQA, Vintners Quality Alliance.

CAD $\$ 8$ or CAD $\$ 8-12$ per $750-\mathrm{mL}$ bottle equivalent, as illustrated in Figure 4. ${ }^{39}$ VQA wines are differentiated by their quality and, not surprisingly, the volume sold at less than CAD $\$ 8$ per $750-\mathrm{mL}$ bottle equivalent was very small. Similarly, the volume in the most expensive category, CAD $\$ 15$ or more, also sold in low volume. The LCBO stores, which allocate a very limited shelf space to Ontario wines in general, may not provide adequate exposure to Ontario VQA wines, especially the most expensive wines. Indeed, it seems to be the choice that wineries, which produce VQA wines in relatively small volumes, select not to market their most expensive wines in LCBO stores. The bulk of VQA table wines sold at retail in two price ranges, CAD \$8-12 or CAD \$12-15 per bottle, had the highest volume sales in October and January.

Retail shipments of VQA wines to LCBO retail stores increased by $53.9 \%$ between $2002 / 03$ and $2010 / 11$, growing

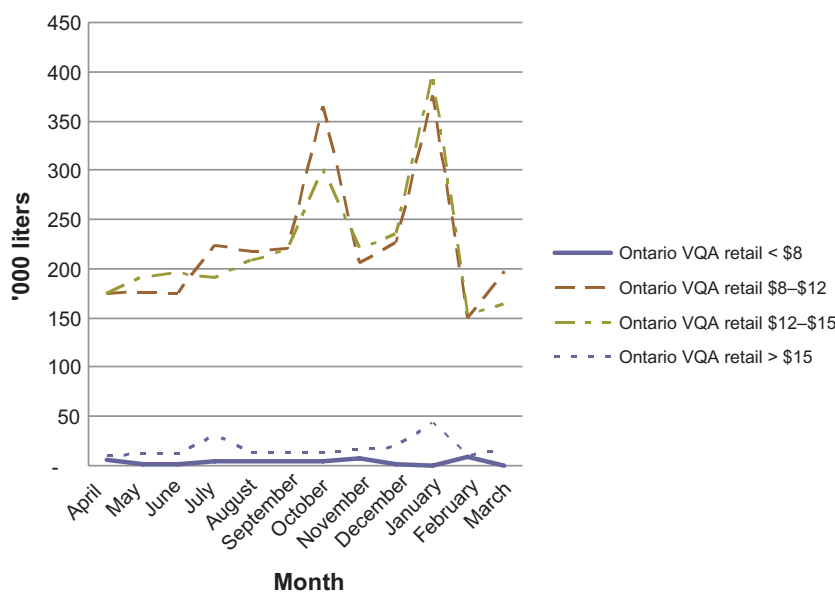

Figure 3 Price categories (750-mL equivalent) for monthly VQA table wines retailed at LCBO stores, April 20I0-March $201 \mathrm{I}$.

Based on data from Wine Council of Ontario (2012). ${ }^{39}$

Abbreviations: VQA, Vintners Quality Alliance; LCBO, Liquor Control Board of Ontario.

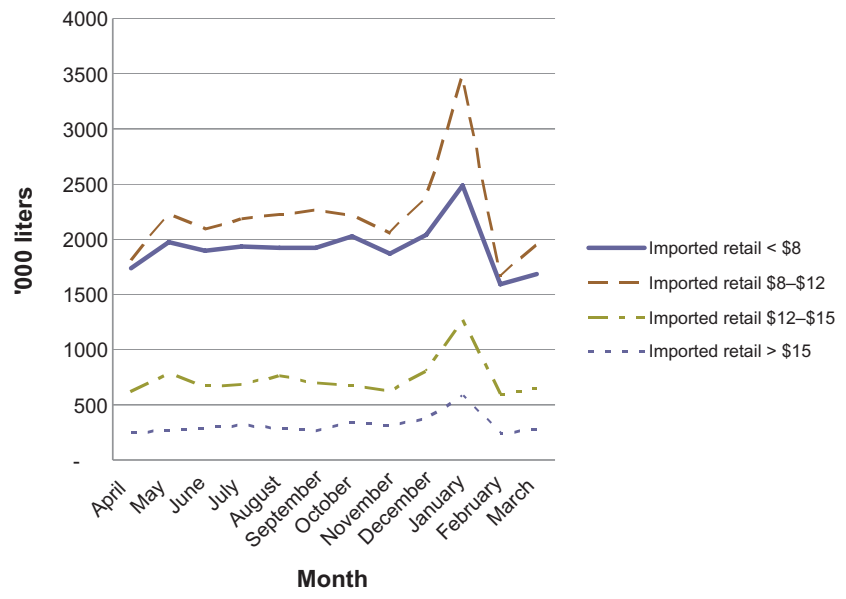

Figure 4 Price categories (750-mL equivalent) for monthly imported table wines retailed at LCBO stores, April 2010-March 2011.

Based on data from Wine Council of Ontario (2012). ${ }^{39}$

Abbreviation: LCBO, Liquor Control Board of Ontario.

faster than shipments to restaurants ( $44.3 \%$ shipment growth) and much faster than shipments to winery retail outlets (22.7\% volume growth), as shown in Table $4 .{ }^{18}$ All wineries are now able to deliver VQA wines directly to restaurants and retain a larger share of the markups otherwise designated for the provincial LCBO monopoly. ${ }^{40} \mathrm{~A}$ recent study argued that, while wineries are not a homogenous group, the sales performance of smaller wineries could benefit if they had greater access to the LCBO distribution system and provided greater shelf space for their products. ${ }^{30}$

The Ontario provincial government has been committed to enhancing the reputation of VQA wines. Since 2010, it has invested (CAD \$6 mln annually) in VQA support programs over a period of 5 years. The Ontario provincial government also invested in tourism-related activities with an annual investment of CAD $\$ 3$ mln over the same period. ${ }^{41}$ Although wine tourism provides additional opportunities for sales, it is highly seasonal and reaches a particular segment of the population, which includes few core wine consumers. The

Table 4 Ontario VQA retail wine sales by marketing channel ('000 liters), 2002-2010 fiscal years

\begin{tabular}{|c|c|c|c|c|c|}
\hline \multirow{2}{*}{$\begin{array}{l}\text { Market } \\
\text { channel }\end{array}$} & \multicolumn{5}{|c|}{ Fiscal year } \\
\hline & $2002 / 03$ & $2004 / 05$ & $2006 / 07$ & $2008 / 09$ & $2010 / 11$ \\
\hline Winery retail & 3650 & 3269 & 2815 & 4041 & 4480 \\
\hline $\begin{array}{l}\text { Licensees } \\
\text { (eg, restaurants) }\end{array}$ & 2073 & 1629 & 2811 & 2813 & 2991 \\
\hline LCBO (shipped) & 4386 & 3276 & 3501 & 5288 & 6751 \\
\hline $\begin{array}{l}\text { Outside of } \\
\text { Ontario and } \\
\text { miscellaneous }\end{array}$ & 1253 & 965 & 818 & 1243 & 1345 \\
\hline Total & 11362 & 9139 & 9945 & 13385 & 15567 \\
\hline
\end{tabular}

Based on data from VQA Ontario (20l la). ${ }^{18}$

Abbreviation: VQA, Vintners Quality Alliance; LCBO, Liquor Control Board of Ontario. 
value of VQA impact on wine tourism accounted for about CAD $\$ 10 \mathrm{mln}$ in $2010 .{ }^{23}$

To reduce the foreign grape content in Canadian wines and enhance the reputation of Canadian-produced wines, the Ontario government announced regulatory changes that encourage local wineries to manufacture wines entirely from domestic grapes and strengthened labeling regulations to allow consumers to differentiate Canadian-content wines from blended wines. ${ }^{42}$

\section{Ontario wine grape production}

Ontario has four principal designated viticulture areas (DVAs): Niagara Peninsula, Lake Erie North Shore, Pelee Island, and Prince Edward County. The Niagara Peninsula is Ontario's largest viticulture area and accounts for over $90 \%$ of Ontario's grape volume production. ${ }^{26}$

The viticulture industry is well established in the province's four DVAs, with the production emphasis on premium $V$ vinifera grapes. The number of grape growers in Ontario decreased from 535 in 1998 to 481 in $2010,{ }^{43}$ while planted grape area increased from 6680 hectares (ha) in 1998 to 7136 ha in $2010 .{ }^{44}$ Commercial plantings of $V$. vinifera grapes increased from 5304 ha in 2000 to 6603 ha in Ontario and account for $60 \%$ of Canadian V. vinifera plantings in 2010, as illustrated in Figure $5 .{ }^{44}$ The expansion of the V. vinifera area in Ontario increased its share in the total grape area planted from $74 \%$ in 2000 to $93 \%$ in 2010 . It is anticipated that the Ontario $V$. vinifera grape area will climb to 8097 ha by $2015 .{ }^{45}$ Ontario grape growers seem to have adapted to the changes resulting from consumer demand, with $V$. vinifera grape area plantings peaking at 7324 ha in 2009.

Grape (V. labrusca, Hybrids, V. vinifera) production has fluctuated over the years, declining to 53,747 tonnes (t) in

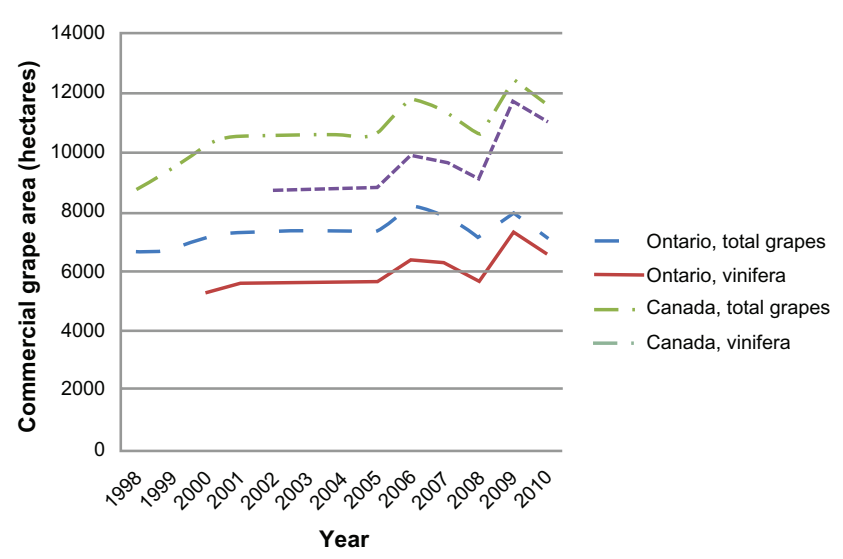

Figure 5 Commercial grape planted area in Canada and Ontario. Based on data from Athwal (20II). ${ }^{44}$

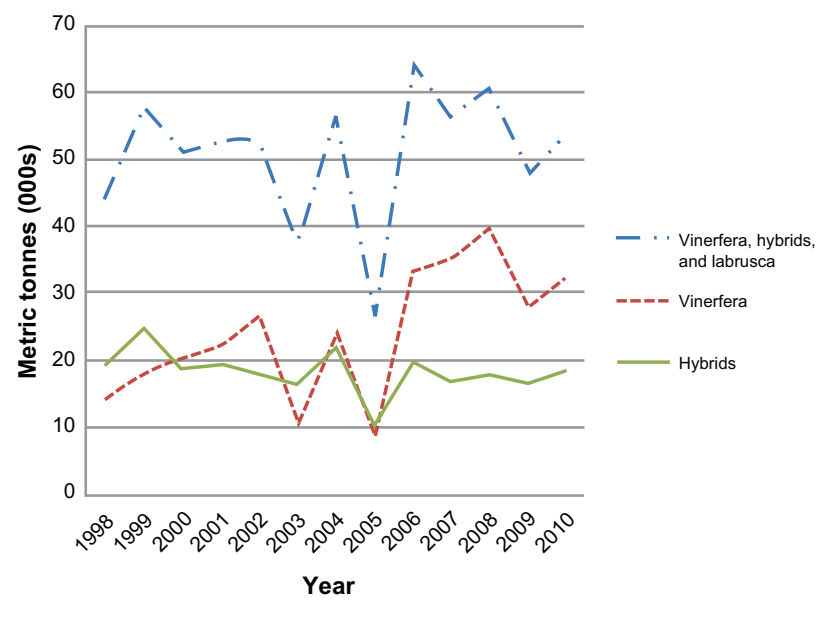

Figure 6 Ontario wine grape production. Based on data from Grape Growers of Ontario (2011). ${ }^{43}$

2010 from a peak of 64,178 $\mathrm{t}$ in $2006 \cdot{ }^{43}$ Between 1998 and 2010 , Ontario grape production increased by $22 \%$, from 44,175 t in 1998 to 53,747 $\mathrm{t}$ in 2010, as shown in Figure 6. ${ }^{43}$ It continued to increase in the latter half of the first decade of 2000 after the weather-induced declines in 2003 and 2005. The shift in wine grape production was attributed to the demand shift for wine type and a greater area planted in V. vinifera varieties. In 2010, Ontario V. vinifera grape production was 32,371 t, which doubled the 1998 production volume. V. vinifera grapes account for roughly $60 \%$ of the Ontario wine grape production harvest, while hybrids account for $32 \%$. The vast majority of French hybrids are grown by independent growers who do not also operate wineries. ${ }^{27}$ While $V$. vinifera grape production has continued an upward trend since 2005, hybrid grape production has somewhat declined since 1999, as illustrated in Figure $6 .{ }^{43}$ Historically, more than $50 \%$ of Ontario's grape crop was earmarked for the lower priced blended wines manufactured primarily

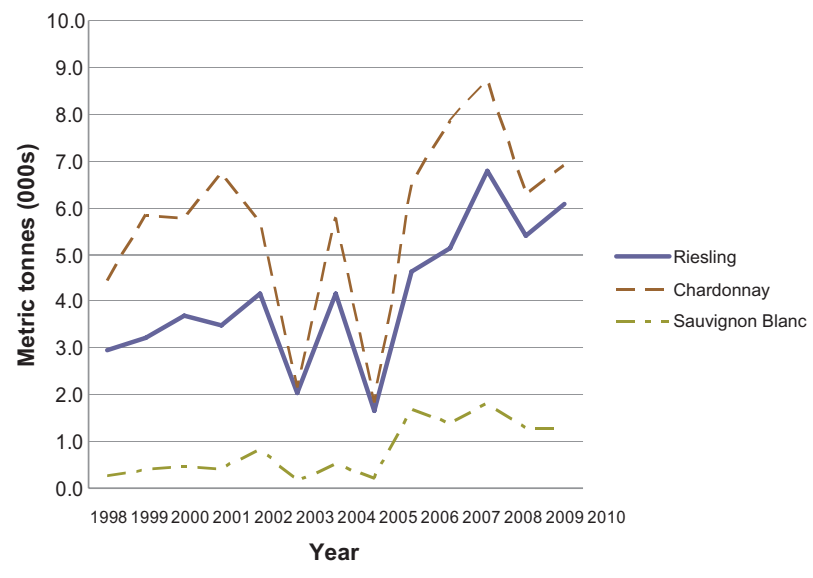

Figure 7 Ontario white wine grape production by selected $V$. vinifera varieties. Based on data from Grape Growers of Ontario (201 I). ${ }^{43}$ 


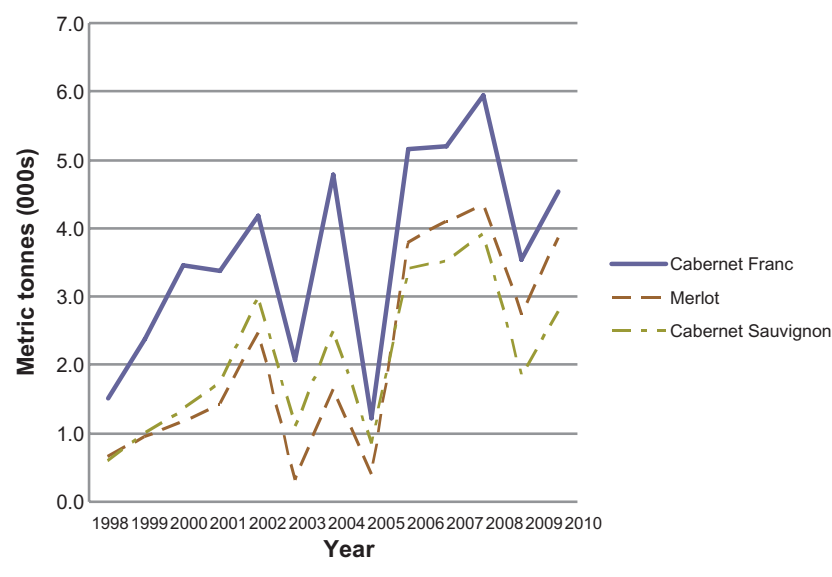

Figure 8 Ontario red wine grape production by selected $V$. vinifera varieties. Based on data from Grape Growers of Ontario (20II). ${ }^{43}$

by the larger wineries. ${ }^{46}$ However, this trend has changed over the last few years, with greater plantings of $V$. vinifera grape varieties for the premium VQA wine market.

The top $V$. vinifera grape varietals grown in Ontario, in terms of production volume, were "Chardonnay," "Riesling," "Cabernet Franc," and "Merlot" (Figures 7 and 8). ${ }^{43}$ It is argued that grape varietal choices in Ontario have been influenced more by winery demand or grower perception than by climatic conditions. ${ }^{47}$ Ontario's Chardonnay wine grape production increased by $56 \%$, from $4424 \mathrm{t}$ in 1998 to $6900 \mathrm{t}$ in 2010, while Cabernet Franc increased by $199 \%$, from $1515 \mathrm{t}$ to $4532 \mathrm{t}$ during the same period (Figures 7 and 8). ${ }^{43}$

The popular grape varietals in the United States, based on Nielsen off-premise wine sales, were Chardonnay followed by Cabernet Sauvignon, Merlot, Pinot Gris, and Pinot

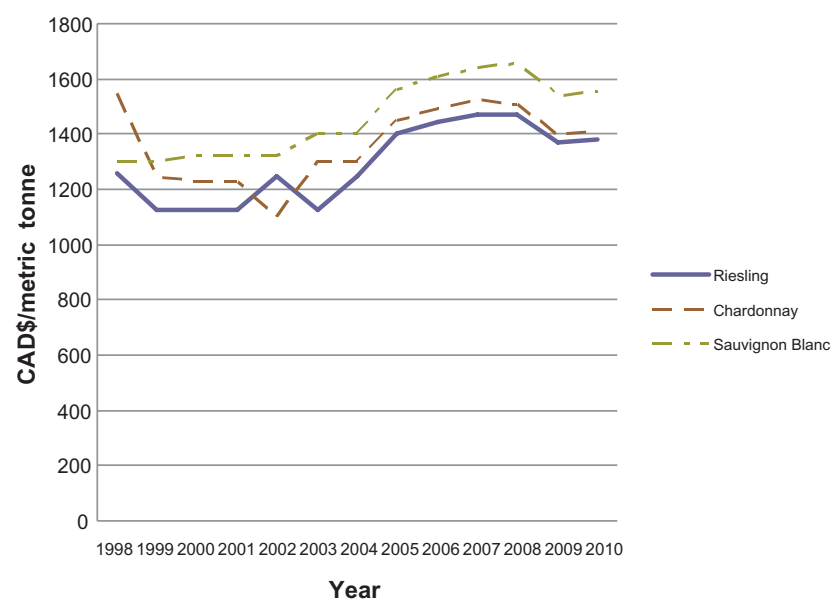

Figure 9 Ontario white wine grape prices of selected $V$. vinifera varieties sold for processing.

Based on data from Grape Growers of Ontario (20I I). ${ }^{43}$

Abbreviation: CAD, Canadian dollar.

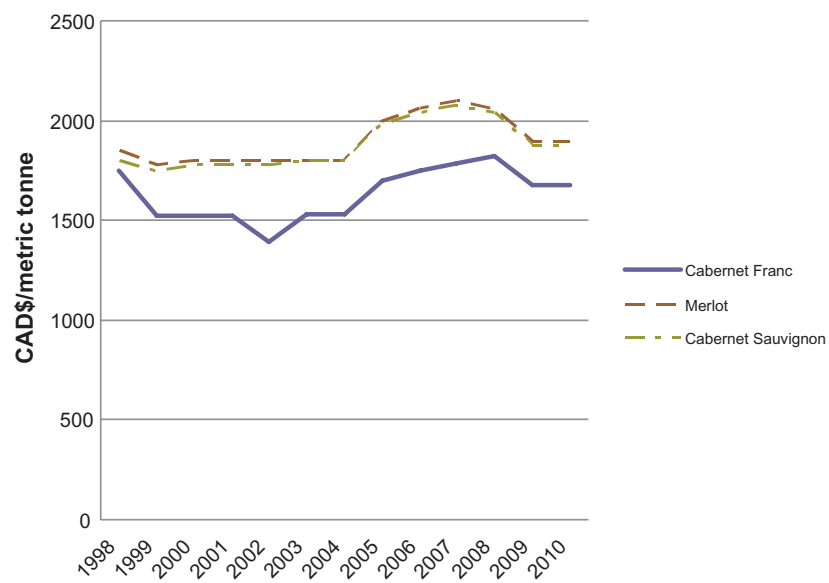

Figure 10 Ontario red wine grape prices of selected $V$. vinifera varieties sold for processing.

Based on data from Grape Growers of Ontario (201 I). ${ }^{43}$

Abbreviation: CAD, Canadian dollar.

Noir. ${ }^{48}$ Some of these varietals have good market potential and grow well in Ontario. Minimum prices for white wine $V$. vinifera grapes have been lower than red varieties sold for processing (Figures 9 and 10). ${ }^{43}$ Among white grape varieties, average unit prices for Sauvignon Blanc were higher than either Chardonnay or Riesling. Since 2004, Cabernet Sauvignon and Merlot minimum prices have been increasing, with both varieties fetching an average base price of approximately CAD $\$ 1900 / t$ in 2010 (Figure 10). ${ }^{43}$ Grape price differences, however, are attributed to varietal differences, soil conditions, and the retail demand for the finished product.

Negotiating equitable and fair grape prices between grape growers and wineries has been fraught with difficulty over the last 6 decades. Negotiated prices established prior to the late 1980s between the WCO and GGO created antagonistic relationships between grape growers and wineries, since grape prices were not based on grape quality and did not reflect the location of the vineyards where the grapes were produced. ${ }^{22}$ Solutions adopted in other countries offer some guidelines as to how to address the conflict. In California, the offering of multiyear planting contracts by wineries to growers has resulted in more predictability in investment decisions by growers and consequently resulted in larger grape plantings. ${ }^{49}$

Since the late 1990s, negotiated grape prices have been based on a sugar scale. However, since July 2010, a pilot pricing model has been established for four grape varieties (Chardonnay, Riesling, Cabernet Franc, and Cabernet Sauvignon) based on their Brix levels. The pricing model includes stepping the scale from the base price to recognize higher quality grapes. ${ }^{50}$ 


\section{Technology development and research institutions}

In Ontario, the earlier grape research undertaken by Agriculture Canada's Vineland Horticultural Research Station has now been assumed by the Cold Climate Oenology and Viticulture Institute (CCOVI) at Brock University. CCOVI has established the research and technological capability to support the technology needs of the Ontario grape and wine sector. The National Research Council of Canada, through the Industrial Research Assistance Program (IRAP), has also provided contributions directly to wineries to bolster their research capacity in developing innovative processes for wine making and viticulture.

In Ontario, the utilization of new oenology technologies, such as refrigeration techniques to control juice and wine temperatures; the application of processing procedures to maintain wine quality; and the adoption of grape presses and fermenters to provide for greater control over wine composition did not occur until the early 1990s after the adoption of the CUSFTA and the establishment of VQA wine quality standards. ${ }^{22}$ Progressive wineries have adopted innovations that include oenology technologies such as yeasts to reduce chemical residues, temperature controls for precision fermentation, and higher quality Canadian oak barrels for maturing premium wines. ${ }^{31}$ Associated with the adoption of new developments in oenology is the global exchange of technical information embodied in the sharing of knowledge and the movement of "Flying Winemakers" from New World countries to Canada. ${ }^{51}$ These trained individuals have bolstered the human capital capacity of Ontario wineries with their expertise in new technologies ranging from refrigeration systems for cooling fermenting juice to processing techniques that mitigate microbial spoilage of wine.

Shifting grape cultivation from hybrid to $V$. vinifera grapes presented production challenges for grape growers in canopy management, rootstock, soil management, and clonal selection. Ontario grape growers have made significant investments in labor saving, quality enhancing, and better winter survival technologies. ${ }^{47}$ Specifically, growers are employing improvements in pruning and leaf thinning and wind machines to reduce grape winter injury.

To mitigate the effects of adverse weather conditions and reduce the incidence of pest and disease problems, integrated grape/winery operations have been growing improved highquality wine grape cultivars that are winter hardy, disease resistant, require less labor to prune and train the vines, and are adapted to local conditions. ${ }^{52}$ Growers have also experimented with non-traditional varieties of hybrid grapes for their cold hardiness and natural disease control. Growing grapes in Ontario under environmentally sustainable viticulture practices has increased over time and a few wineries have adopted organic and biodynamic production practices. ${ }^{53}$

\section{Conclusion}

Despite a myriad of government regulations operating at different segments of the grape/wine supply chain, the Ontario wine sector has made significant gains over the last decade, as characterized by aggressive new plantings of $V$. vinifera varietals, expansion in the number of VQA wineries, technology innovation in viticulture and oenology, and greater recognition of Ontario as a region that produces premium quality wines. Despite increasing import competition, sales of VQA wines are increasing, especially at higher price points (eg, CAD \$12-15), attributed to increasing disposable incomes and lifestyle changes of the aging population.

The wine regulatory regime, as manifested by policies such as VQA and the wine labeling laws, has been amended over the last few years to improve the competitiveness position of small/mid-sized wineries. These policy changes are likely to be useful in the future as Ontario increases its exports of premium quality wines. Because of economies of scale and increasing land values, small- and medium-sized Ontario wineries cannot compete with imported wines at less than CAD $\$ 8 /$ bottle of wine ( $750-\mathrm{mL}$ equivalent sales). The lower priced wines are the price categories where the large wine companies would have a competitive edge, since they produce and market larger volumes of ICB-branded products, coupled with a wider network of domestic retail stores to merchandize their product.

The survival of the Ontario wine industry (eg, small/ mid-sized winery operations) calls for greater retail access, "getting prices right," and developing product and process innovations, including flagship varietals. Multiple-year grape price contracts to provide greater predictability in vineyard investment decisions ought to be established. These need to reflect wine quality and geographical differences among sub-appellations.

Public/university/industry R\&D partnerships have recently been established, as evidenced by the Developing Innovative Agri-Products (DIAP) project to improve wine quality and develop better information tools to protect growers from cold weather events. ${ }^{52}$ An increase in vine productivity, given the limited amount of land for vineyard expansion, must be addressed through the development of improved grape vine cultivars. Although the Plant Breeders' Rights (PBR) Act was enacted in 1990, there is little evidence in 
Canada to suggest it has stimulated the development of many new grape vine cultivars. To date, of the nine grapevine PBR applications filed in Canada, five are for $V$. vinifera, three of which were filed by the University of Minnesota cold hardy grape breeding program..$^{54}$

\section{Disclosure}

The authors report no conflicts of interest regarding their published work.

\section{References}

1. VQA Ontario. Annual Report. Toronto, Ontario. 2004.

2. Aspler T. The Wine Atlas of Canada. Random House Canada. Toronto, Ontario. 2006.

3. Hope-Ross P. From the Vine to the Glass: Canada's Grape and Wine Industry. 2006. Available from: http://www.statcan.gc.ca/pub/11-621-m/ 11-621-m2006049-eng.pdf. Accessed November 2, 2009.

4. Agriculture and Agri-Food Canada. The Canadian Wine Industry. 2011. Available from: http://www4.agr.gc.ca/AAFC-AAC/displayafficher.do?id=1172244915663\&lang=eng. Accessed February 2, 2012.

5. Wine Council of Ontario. The Wines of Ontario: Building a worldclass brand: Sales and Marketing Plan. 2001. Available from: http:/ winecountryontario.ca/. Accessed August 29, 2011.

6. Statistics Canada. Principal statistics for manufacturing industries (Table 3010006), by North American Industry Classification System. 2011a. Available from: http://estat.statcan.gc.ca/cgi-win/cnsmcgi.exe?Lang=E\&amp;ESTFi=EStat/English/CII_1-eng.htm. Accessed August 22, 2011.

7. Jordan K. The Canadian Wine Industry: A Summary View. Special Report from Bank of Montreal Capital Markets Economics. Toronto, Ontario. 2011.

8. Fisher C. Wine Business Monthly. 2010 (February). Available from: http://www.winebusiness.com/wbm/?go=getArticle \&dataId=72744. Accessed September 9, 2011.

9. Statistics Canada. Sales of alcoholic beverages (Table 183-0006) by volume, value and per capita 15 years and over, by fiscal years. 2011b. Available from: http://estat.statcan.gc.ca/cgi-win/cnsmcgi. exe?Lang=E\&amp;EST-Fi=EStat/English/CII_1-eng.htm. Accessed September 15, 2011.

10. Statistics Canada. Control and sale of alcohol beverages. 2011c. Available from: http://www.statcan.gc.ca/daily-quotidien/110420/ dq110420a-eng.htm. Accessed September 9, 2011.

11. Guilbault K. Agriculture and Agri-Food Canada. Ottawa, Ontario. Special Tabulation Trade Data Request. 2011.

12. Kosco S. United States Department of Agriculture, Foreign Agricultural Service. Washington, D.C. Personal Communication. 2011.

13. O'Dell and Associates. A National Export Strategy for Canadian Wines. Report prepared for the National Export Working Group and Foreign Affairs and International Trade Canada, Ottawa, Canada. 2009.

14. Jenish D. Cool wines, hot market. Maclean's Magazine. August 27, 2001:39.

15. Jones G, Hirasawa J. Inniskillin and the Globalization of Icewine. Harvard Business School Case Study. 2008; No 9-805-129.

16. Statistics Canada. Estimates of population, by age group and sex (Table 051-0001) for Jul 1, Canada, provinces and territories, annual (persons); Sales of alcoholic beverages of liquor authorities, wineries and breweries (Table 183-0015), by value and volume, fiscal year. 2011d. Available from: http://estat.statcan.gc.ca/cgi-win/cnsmcgi.exe?Lang=E\&amp;EST$\mathrm{Fi}=\mathrm{EStat} /$ English/CII_1-eng.htm. Accessed August 26, 2011.

17. Lapsely JT. Looking forward: Imagining the market for California wine in 2030. Agricultural and Resource Economics Update (Special Issue: The World of Wine: Economic Issues and Outlook). Giannini Foundation of Agricultural Economics, University of California. 2010;13(6):12-15.
18. VQA Ontario. VQA Annual Reports (Various years). 2011a. Available from: http://www.vqaontario.ca/Resources/Library. Accessed September $30,2011$.

19. British Columbia Wine Institute. Annual Report (Various years). 2011. Available from: http://www.winebc.com/publications.php. Accessed September 29, 2011.

20. Hudec A. Reforming Canada's wine laws. 2009. Available from: http:// www.farris.com/images/uploads/ALH_-_Reforming_Canadas_Wine_ Laws.pdf. Accessed November 3, 2009.

21. Scott J. The Canadian wine market - regulated but rewarding. Australia and New Zealand Wine Industry Journal. 2009;24(1):41-42.

22. Bramble L, Cullen C, Kushner J, Pickering G. The Development and Economic Impact of the Wine Industry in Ontario, Canada. In: Campbell G, Guibert N, editors. Wine, Society, and Globalization: Multidisciplinary Perspectives on the Wine Industry. New York: Palgrave Macmillan; 2007:63-86.

23. KPMG. Study of the Ontario Economic Impact of Ontario VQA Wines. Report prepared for the Wine Council of Ontario. 2011.

24. Amold E. Ontario Grape Shortage Leads to Rule Change on Blending. Wine Spectator. 2005. Available from: http://www.winespectatot.com/ webfeature/show/id/. Accessed August 31, 2011.

25. VQA Ontario. Wines of Ontario. Canada; 2011b. Available from: http:// www.vqaontario.ca/Library/Documents/OntarioWineOverview.ppt. Accessed September 30, 2011.

26. VQA Ontario. 2011c. Grape and Wine Production: Wine production facts. 2011c. Available from: http://www.vqaontario.com/Wines/ GrapeWineProduction. Accessed September 30, 2011.

27. Ontario Wine Industry Reference Book. Prepared by the George Morris Centre for the Wine Secretariat, Government of Ontario. 2008.

28. Migone A, Howlett M. Comparative Networks and Clusters in the Wine Industry. American Association of Wine Economists. AAWE Working Paper. 2010:No 62. Available from: http://www.wine-economics. org.

29. Mytelka LK, Goertzen H. Learning, Innovation and Cluster Growth: A Study of Two Inherited Organizations in the Niagara Peninsula Cluster. United Nations University. Institute for New Technologies. Discussion Paper Series; 2004:\#2004-2015.

30. Nash NA. Going Local: An examination of the LCBO and the Ontario wine industry. McMaster University, Department of Communication Studies and Multimedia. 2010. Available from: http://digitalcommons. mcmaster.ca/cmst_grad_research/1. Accessed April 16, 2012.

31. Mytelka LK, Goertzen H. Vision, Innovation, and Identify: The Transformation of a Wine Cluster in the Niagara Peninsula. In: Rama R, editor. Handbook of Innovation in the Food and Drink Industry. The Haworth Press and Taylor Group, New York. 2008:323-358.

32. Grape Growers of Ontario. What's in a bottle?; 2012. Available from: http://www.grapegrowersofontario.com/node/68. Accessed February 2, 2012.

33. Bramble L. Niagara's Wine Visionaries: Profiles of the Pioneering Winemakers. Lorimer. Toronto, Ontario. 2009.

34. The Economist. Canada's wine industry: outsourcing terroir. September 12, 2009:44.

35. Ejbich K. Protest Mounts Over "Cellared in Canada" Wines. Wine Spectator. 2009. Available from: http://www.winespectator.com/ webfeature/show/id/40551. Accessed August 31, 2011.

36. Gibson D. Wine Council of Ontario. Vineland, Ontario. Personal Communication. 2011.

37. Harling K. Business strategies as a market opens: A case study of Ontario wineries. Agribusiness. 1994;10(3):259-273.

38. Statistics Canada. Median total income, by family type, by census metropolitan area. 2011e. Available from: http://www40.statcan.gc.ca/101/ cst01/famil107a-eng.htm. Accessed September 21, 2011.

39. Wine Council of Ontario. Special Tabulation Data Request. 2012.

40. Sanderson B. Canada's Revival: Impressive new Chardonnays, Rieslings and Ice Wines reflect a transformation in the vineyards. Wine Spectator. 1999. Available from: http://www.winespectator.com/ magazine/show/id/8384. Accessed September 23, 2011. 
41. Ontario Government. Ministry News - Supporting Ontario's Wine and Grape Industry, McGuinty Government Strengthens VQA Wines. 2010. Available from: http://www.sse.gov.on.ca/mcs/en/Pages/ News_28 Apr2010.aspx. Accessed September 8, 2011.

42. Wingrove J. Ontario raises a toast to local wine with new labelling, tax measures. The Globe and Mail. October 14, 2009:A4.

43. Grape Growers of Ontario. Annual Reports (Various years). St Catharines, Ontario; 2011. Available from: http://www.grapegrowersofontario.com/ annual-reports. Accessed April 16, 2012.

44. Athwal R. Statistics Canada, Horticulture Division. Ottawa, Ontario. Special Tabulation Data Request for Grape Area in Ontario and Canada, 1998-2010. Personal Communication. 2011.

45. Canadian Grape and Wine Research Strategy. Championing a Winning Example for Canadian Agriculture. 2007. Available from: http://www. canadianvintners.com/news/documents/GrapeandWineResearch Strategy2007.pdf. Accessed September 22, 2009.

46. Wine Council of Ontario. The Ontario Wine Industry 2003 Year in Review. Vineland, Ontario. 2003.

47. Mussell A, Stiefelmeyer K, Oginskyy A. Schmidt C, Seguin B. 2010. Aligning the Ontario Grape Supply and Demand: A Varietal Plan for the Grape and Wine Industry. Final Report prepared by the George Morris Centre for the Ontario Grape Growers Association. 2010. Available from: http:/www.grapegrowersofontario.com/sites/default/ files/pdf/Varieta1\%20Plan\%20Executive\%20Summary\%20Dec-10. pdf. Accessed January 20, 2012.
48. The Wine Economist. Retail wine sales: Big versus hot. 2010. Available from: http:/wineeconomist.com/2010/11/30/retail-wine-sales-bigversus-hot-hot-hot/. Accessed January 25, 2012.

49. Goodhue RE, Heien DM, Lee H, Sumner DA. Contract use widespread in wine-grape industry. California Agriculture. 2002;56(3):97-102.

50. Grape Growers of Ontario. Newsletter. Jul 2010; 6:1-8. Available from: http://www.grapegrowersofontario.com. Accessed December 12, 2011.

51. The Wine Economist. Flying winemakers and the globalization of wine. 2008. Available from: http://wineeconomist.com/2008/07/20/ flying-winemakers-and-the-glocalization-of-wine/. Accessed February 1, 2012.

52. Combe MJ. Grape Growers of Ontario. St Catharines, Ontario. Personal Communication; 2012.

53. Kwong LMK, Cyr D, Kushner J, Ogwang T. A semiparametric hedonic pricing model of Ontario wines. Canad ian Journal of Agricultural Economics. 2011;59:361-381.

54. Canadian Food Inspection Agency (CFIA). Plant Breeders' Rights Database; 2012. Available from: http://www.inspection.gc.ca/english/ plaveg/pbrpov/cropreport/grae.shtml. Accessed February 10, 2012.
International Journal of Wine Research

\section{Publish your work in this journal}

The International Journal of Wine Research is an international, peer-reviewed open-access, online journal focusing on all scientific aspects of wine, including: vine growing; wine elaboration; human interaction with wine; and health aspects of wine. The journal provides an open access platform for the reporting

\section{Dovepress}

of evidence based studies on these topics. The manuscript management system is completely online and includes a very quick and fair peer-review system, which is all easy to use. Visit http://www.dovepress.com/testimonials.php to read real quotes from some of our published authors. 